Bulletin of the Natural History Museum, 2013, 6: 71-74.

Received 24 Jan 2013; Accepted 04 Sep 2013.

DOI: $10.5937 / \mathrm{bnhmb} 1306071 \mathrm{M}$

UDC: $595.76(497.11)$

Short communication

\title{
SPHAERIUSIDAE (COLEOPTERA, MYXOPHAGA) - A NEW BEETLE FAMILY TO THE FAUNA OF SERBIA -
}

\author{
GABOR MESAROŠ \\ Lazarevačka 2, 24000 Subotica, Serbia, e-mail: gabor@mesaros.net
}

Myxophaga, the second smallest suborder of Coleoptera after Archostemata, consists of approximately 65 species of small to minute beetles in four families. The members of this suborder are aquatic or semi-aquatic and feed on algae. Till now only the family Hydroscaphidae was known in Serbia, represented by one species - Hydroscapha granulum Motchulsky, 1885 (Löbl 2003).

The family Sphaeriusidae was previously known as "Sphaeriidae Erichson, 1845", but the name was found to be preoccupied by a family of freshwater clams. Being a junior homonym of a molluscan family Sphaeriidae Jeffreys, 1862 (1820), the name was replaced by Microsporidae Reichardt, 1976 (based on the type genus Microsporus, Waltl 1838) (Melville 1985). However, this action created a number of new problems and caused nomenclatural and taxonomic instability in the family. To resolve the problems, by the ruling of the plenary power the International Commission on Zoological Nomenclature (ICZN) decided to emend the spelling from Spheriidae to Sphaeriusidae (2000, Opinion 1957).

Beetles of the family Sphaeriusidae are distributed on all continents except Antarctica, typically occurring along the banks of streams and rivers. This monotypic family contains only a single genus, Sphaerius 
Waltl, 1938, that comprises 23 species (Maddison 1995). Eight species occur in the Palaeartic and three of them are known in Europe (Löbl 2003).

The mud beetle Sphaerius acaroides Waltl, 1938 is the only member of the family Sphaeriusidae found so far in Serbia. It is a tiny beetle (total length ranges $0.5-0.75 \mathrm{~mm}$ only), short oval and very convex in form, entirely black or dark brown, glabrous and shiny (Fig. 1). The species exhibits a combination of some unique characteristics: the head is prominent, with relatively large eyes set far apart; the antennae are 11 segmented with an elongate 3-segmented hairy club; there are distinct notopleural sutures on the prosternum; only three abdominal sternites are visible and the hind coxae are expanded into very large femoral plates. The legs are short with broad and flat tibiae with a prominent tooth at the external edge, especially on the frontal pair. These beetles occur in a variety of damp environments, including mud, wet loamy, sandy or gravelly substrate on the shores of rivers, and stagnant water bodies. They store some air underneath their elytra. Females produce a single large egg at a time (Maddison 1995).

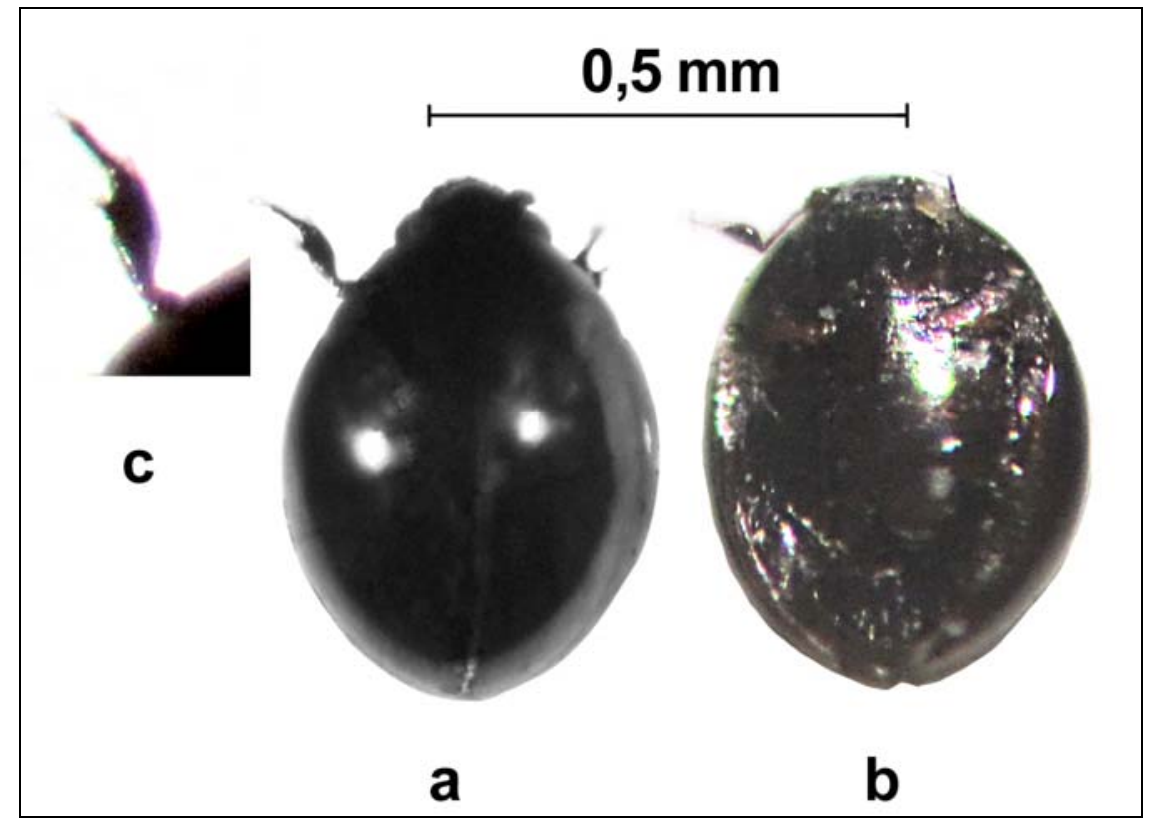

Fig. 1. - External habitus of Sphaerius acaroides. a) dorsal side, b) ventral side c) fore tibia (Photo: Andjelka Popovic).

The species is widely distributed throughout most of Europe except for the Iberian Peninsula, and it also reported from the Caucasus (Löbl 2003). Recent investigations confirm this species in several localities in Hungary and Romania (Merk1 1998, 2001, 2008). 
During extensive investigation of aquatic beetles of Vojvodina, over one hundred of these tiny mite-like beetles were first collected in a sample of shore detritus from Majdan Pond in Kelebia, sifted by a Reitter litter sifter and extracted in a laboratory by a Berlese funnel (12 September 2011 $\left.-46^{\circ} 9^{\prime} 29.08^{\prime \prime} \mathrm{N}, 19^{\circ} 36^{\prime} 26.10^{\prime \prime} \mathrm{E}\right)$. This finding was repeated using the same methodology at the same place during 2012. More specimens were collected, also in great numbers, at the nearby Kelebijsko Jezero Lake (14 June 2012 - 46 $\left.{ }^{\circ} 8^{\prime} 28.17^{\prime \prime} \mathrm{N}, 1^{\circ} 34^{\prime} 45.84^{\prime \prime} \mathrm{E}\right)$. Five more specimens were collected at the Danube flooding zone near Bogojevo (28. July 2012 $45^{\circ} 32^{\prime} 18.40^{\prime \prime} \mathrm{N}, 19^{\circ} 4^{\prime} 16.24^{\prime \prime E}$ ). Using the keys of Negrobov (2005) and Hájek (2007) the collected specimens were identified as Sphaerius acaroides. Specimens are deposited in the collection of the author.

All examined habitats are located on the shore of stagnant water, on a sandy substrate not fully overgrown with emergent vegetation, but with high humidity and a significant quantity of decomposing dead leaves of reed (Phragmites australis) and sedges (Carex spp.).

This species can be easily overlooked due to its small size and secretive way of life and it is probably much more widespread in Serbia than suggested by these findings.

References: HÁJEK, J. (2007): Icones Insectorum Europae Centralis: Coleoptera Sphaeriusidae, Gyrinidae, Haliplidae, Noteridae, Paelobiidae. - Folia Heyrovskiana, serie B 9: 1-13; INTERNATIONAL COMMISSION ON ZOOLOGICAL NOMENClATURE (2000): Opinion 1957: Sphaerius Waltl, 1838 (Insecta, Coleoptera): conserved; and Sphaeriidae Erichson, 1845 (Coleoptera): spelling emended to Sphaeriusidae, so removing the homonymy with Sphaeriidae Deshayes, 1854 (1820) (Mollusca, Bivalvia). - Bulletin of Zoological Nomenclature 57(3): 182-184; LÖBL, I. (2003): Shaeriusidae Erichson, 1845. In: LöBL, I. \& SMETANA, A. (eds): Catalogue of Paleartic Coleoptera 1: Archostemata - Myxophaga - Adephaga. Apollo Books, Stenstrup; MADDISON, D. R. (1995): Sphaeriusidae. Minute Bog Beetles. Ver. 01 January 1995. http://tolweb.org/Sphaeriusidae/-9053/1995.01.01 in The Tree of Life Web Project, http://tolweb.org/; MeLVILLE, R. V. (1985): Opinion 1331: Sphaeriidae Jeffreys, 1862 (1820) (Mollusca, Bivalvia) and microsporidae Reichardt, 1976 (Insecta, Coleoptera): placed on the official list. - Bulletin of Zoological Nomenclature 42: 230-232; MERKL, O. (1998). Data to 46 beetle families (Coleoptera) from the Duna-Dráva National Park, South Hungary. - Dunántúli Dolg. Term, tud. Sorozat 9: 209-232; MERKL, O. (2001): Data to 34 families for the catalogue of beetles (Coleoptera) of Somogy megye. - Natura Somogyiensis 1: 191-212 [in Hungarian]; MerkL, O. (2008). Data to the knowledge on the beetle fauna of Maramureş, Romania (Coleoptera). - Studia Universitatis "Vasile Goldiş", Seria Ştiințele Vieţii (Life Sciences Series) 18, suppl.: 243-311; NEGROBOV, S. O. (2005): Illustrated keys to families of beetles in European Russia. - Voronezh State University, Voronezh [in Russian]. 


\title{
SPHAERIUSIDAE (COLEOPTERA, MYXOPHAGA) \\ - НОВА ПОРОДИЦА ТВРДОКРИЛАЦА ЗА ФАУНУ СРБИЈ -
}

\author{
И 3 В О Д
}

Sphaerius acaroides из породице Sphaeriusidae (подред Мухорhaga) је први налаз за подручје Србије. По својој величини од око 0,6 мм, представници ове врсте су свакако најситнији тврдокрилци у фауни Европе. Бројна популација Sphaerius acaroides откривена је у периоду 2011-2012, у узорцима обалске стеље на обали баре Мајдан и Келебијском језеру (Келебија код Суботице) а у 2012. години и на подручју Горњег подунавља, у плавном делу Дунава код Богојева. С обзиром на еколошке преференце, ова врста тврдокрилаца највероватније има много веће распрострање у Србији. 